\title{
URBAN REGULARISATION OF BELGRADE, 1867: TRACE VS. ERASURE
}

\author{
A B S T R A C T
}

A gradual urban transformation of Belgrade from Oriental into Occidental city in the nineteenth century in a way prefigured its political change of status from an Ottoman Empire border town into a capital of a European nation state (i.e. the Principality of Serbia internationally recognised in 1878). This paper will explore this process, and will focus on the analysis of the plan of regularisation of Belgrade (1867), by Emilijan Josimović, the first Serbian urbanist. Josimović's plan laid down proposals for a total reconstruction of the Ottoman urban structure, and consequent transformation of Belgrade into European planned city. Radical though it was, the Plan gave urbanistic rationale and formalisation to what already lasted as an informal process of re-urbanisation parallel to the liberation from the crumbling Turkish rule and the related political processes. 
Belgrade's position at the confluence of the river Sava into the Danube, is marked historically by the condition of constantly shifting borders of divided and conflicting empires. The river Sava marked a geographical and political borderline from the fourth century division of the Roman Empire into the Eastern and Western Empires, until the mid-twentieth century Third Reich's remapping of Europe. Belgrade's geographical position is perhaps best illustrated by the eighteenth century engraving "Plan and Panorama of Belgrade (Alba Graeca)", by Matias Seutter, which shows the city and its fortifications in the context of rich and dramatic landscape. ${ }^{1}$ Its historical and political situation of unremitting shifting, in this case between the Ottoman and the Habsburg empires, could be understood from the engraving by Quirin Mark, showing the conquest of Belgrade by the Field Marshall von Laudon in 1789. ${ }^{2}$ That same year, the city itself is best recorded in the plan surveyed by Franz von Brusch for the purpose of the Austrian occupying administration. ${ }^{3}$ It shows the urban structure of the Oriental city with unregulated winding street network, which remained largely unchanged in the next seventy-five years. Even after the Serbs gained limited authority over Belgrade in the second quarter of the nineteenth century, the changes within the urban structure were of mere architectural nature. Those changes were limited to construction of buildings which showed clear orientation to Western models and the ambition of the authorities to follow after the European trends, though refracted strongly through the prism of the dominating Austrian economic and cultural influence. The planning lagged behind architectural design, and then for a long period it was sidelined to free territory in suburban parts outside the town proper.

\section{ARCHITECTURE AND PLANNING OF BELGRADE IN THE LIBERATED SERBIA}

After passing the 1830 Turkish Law (Hatišerif), Belgrade was a seat to both the Serbian and the Turkish administration, remaining the only Serbian town where the Turkish civilian population was still permitted to live freely, albeit no new settlers were allowed in. The town space was structured into three principal parts, the town proper encircled by the Moat and palisade embankments, the Fortress, held by the Turkish garrison, separated from the town space by the wide Kalemegdan field, and the village-suburbs outside the Moat. The civilian Turkish population concentrated on the side of the town sloping towards the Danube, the Jewish population inhabiting the lower areas, and the Serbian population formed its centre on the opposite side of town sloping towards the river Sava, and also inhabited the village-suburbs. ${ }^{4}$ 
The first buildings signifying the Serbian rule, constructed under the Prince (knez) Miloš were carried out by Hadži Nikola Živković, the first qualified master builder in the liberated Serbia. ${ }^{5}$ The first is the residence of the Princess (kneginja) Ljubica (1831), located in the Serbian town centre, and the second is Prince Miloš's residence, which was constructed far out of town in Topčider, at a safe distance from the Turkish guns (1833). The architecture of both buildings is of the Balkan-Oriental type, but constructed in brick imported from Austria, and showing some Western influence in the decoration of facades. The Western architecture model was introduced by the Slovak engineer Franz Janke, who came to Serbia from Austria in 1834, and worked as an architect, civil engineer and urbanist in Belgrade until 1843. He designed some of the most important buildings in the Serbian town centre, namely, the Custom House (Đumrukana, 1835), and the Cathedral Church (Saborna crkva, 1837-1841; 1845), as well as a fine classicist house of Cvetko Rajović, later the Belgrade Realschule (1837).

The work that is of major significance is Janke's work on civil engineering projects, such as that on the river port on the Sava, as well as his urban planning of parts of Belgrade outside the Moat, which is particularly noteworthy, notwithstanding partial scope of the plans themselves. With regard to urban planning in the $1830 \mathrm{~s}$, it is important to note that due to unfeasibility of major urbanistic intervention in the Turkish populated parts of town and the Fortress, the planning of the inner city taken as a whole was at a standstill. The interventions in the Serbian parts of the inner city were of a limited scope, restricted to partial regulations of existing streets and land parcels to accommodate for traffic and relatively orderly layout of the new buildings. ${ }^{6}$ The only major urban planning strategy of this period, albeit partial in scope, was developed for the suburbs outside the Moat. These parts were regularised and developed by direct order of Prince Miloš, as Serbian populated areas with notable commercial function. Janke's planning was also part of the outer city development, such as that of the suburb Savamala (Abadžijska čaršija), and the area of regular urban structure with streets and boulevards of $38 \mathrm{~m}$ width (Kneza Miloša, Nemanjina, Bulevar kralja Aleksandra), which, still today, remain one of the most generously planned parts of the historical city. The clear distinction between the inner and outer parts of the city, i.e., nonregularised Ottoman Oriental inner city and the regularised outer suburbs, and the consequent difference of planning paradigm, is best recorded in the Austrian plan by captain König, from 1854. As noted in the study of the cartographic sources by Željko Škalamera: "This is the first known plan from the mid-nineteenth century which presents the whole urban situation and the 
results of development of Belgrade in the preceding period, and it is, for the time being, the only known source which fixes the spatial development of Belgrade outside the Moat". ${ }^{7}$ What this plan clearly shows is the unevenness of development across the urban area of Belgrade, and, most notably, the condition of disconnectedness between the Fortress and the inner city on the one side, and the inner and the outer city on the other side.

With the increasing number of engineers educated in the West (mostly in Austria), the general characteristic of Belgrade architecture of this period is the orientation towards Western models, paralleled by disregard and subsequent dilapidation of the Ottoman architecture (e.g. out of some fifteen surviving mosques, only one remained in function) ${ }^{8}$ Also, in the changing political climate, with the mass moving out of the Turkish population, which was completely finalized in 1867 , the town changed its profile along with the change of its government and its population. ${ }^{9}$ Belgrade became the capital of the vassal state of Serbia in 1841, and thereafter the capital of the Principality of Serbia. By the time the Turks left for good, Belgrade appeared as a hybrid Oriental-Occidental city, its urban structure swaying between the extant Ottoman morphology and the constantly slipping away European paradigm. With quite significant development of the suburbs, the urban structure of Belgrade within the Moat remained most critical, and totally cut off from the rest of the city.

The one to fully understand this momentum of change of paradigm, and to recognise it as the turning point for the future of Belgrade as a European city, was Emilijan Josimović, the mathematician and the architect educated in Vienna. ${ }^{10}$ Josimović came to Belgrade in 1845, and was appointed the professor of the Lyceum/College School (Velika škola). As a preamble to his undertaking of urban regularisation, he first introduced teaching of architecture at the College School and in 1860, he published the book "Civic Architecture and Construction of Roads" [Građanska arhitektura i građenje putova]. The book is structured under the headings of longevity, comfort, and beauty of buildings, and it underlines duality of technical and aesthetic nature of architecture. ${ }^{11}$ Specifically accentuated is the importance of natural environment, the point Josimović will have made an important part of his planning strategy in the following years. I would argue that Emilijan Josimović's planning can be seen, as it were, ecological urbanism avant la lettre.

In 1864, the Belgrade fortress still being under the Turkish command, Josimović undertook detailed geodetic survey of Belgrade, with the most 
importantexisting buildings marked as worth preserving. This survey remains the most comprehensive document of urban structure of Belgrade before the reconstruction. At the time of the survey, the number of significant buildings of European architectural character were built or were under construction, to name but a few commercial buildings, Large Brewery (1839), Hotel "Kod jelena" (1841), as well as public ones, such as the Ministry of Finances (1836), and City Hospital (1865). The most representative of all public buildings constructed in this period, was the Captain Miša's Foundation (1863), by the architect Jan Nevole. Donated as a public building for cultural and educational purposes, it consequently housed the College School, the Grammar School, the Ministry of Education, the National Library and Museum. Following immediately after the regularisation plan, was the construction of the National Theatre (1868-69), by Aleksandar Bugarski. In this period, a number of old Turkish mosques still remained in the city, yet all but one were demolished until the beginning of the twentieth century. ${ }^{12}$

On the basis of his survey Josimović prepared the regularisation plan, and published it in 1867 under the title, translated here as: "Explanation of the proposal for urban regularisation of that part of Belgrade which lays within the Moat, with one lithographic plan in the scale of 1/3000". ${ }^{13}$ Josimović was a contemporary to the famous European urbanists Georges-Eugène Haussmann (1809-91), and Ildefons Cerdà (1815-76), and his plan followed soon after their famous plans for reconstruction of Paris (1853-71), and Barcelona (1859-70). It was, however, the reconstruction of Vienna as conceived by Franz Joseph I, and carried out by the architect Ludwig Förster and others in the period between $1857-70$ s, that is most relevant as a point of reference. Josimović's plan demonstrates the universality of the European planning paradigm of the period, and more precisely of the ring principle which was employed in Vienna, yet it clearly brings out the specific character of Belgrade into its proposals for reconstruction.

\section{PROPOSAL FOR URBAN REGULARISATION OF BELGRADE BY EMILIJAN JOSIMOVIC}

Emilijan Josimović undertook the work on the survey of Belgrade mostly as a private individual, or rather as an enthusiastic scientist or researcher, publishing his findings at his own expense and addressing the general public as much as he addressed the authorities, and in that aspect his work is similar to Cerdà's. As he writes in the Preface to his Explanation of proposal for urban regularisation of that part of Belgrade which lays within the Moat: 
After some three years long work, the great efforts made and a waste of time in surveying the town and making a proposal for its regularisation, with so many unfavourable circumstances suffered (which were caused) by the 11 parties in this business, - and finally myself being at a considerable financial loss personally as a consequence of it, - I thought: the least of all sacrifices made for such a useful thing would be if I published this project explanation at my own expense, with no profit for myself whatsoever - and, thus the book was published. ${ }^{14}$

The book is forty-seven pages long and structured in five chapters. In the introductory Chapter I, there is an explanation of the plan of existing town with regard to the principal defects of uneven, congested and unhygienic urban structure, and traffic problem of disproportionately long or short streets of widely varying widths, combined with a great number of (more than forty) dead-end streets. It is pointed out that the city of some 900,000 m.sq. has only one market and one church in the inner city. It specifically underlines the absence of open green areas - "reservoirs of air (vazdušni rezervoari)" especially scarce after the Turks left their houses and their lush gardens have been "exterminated (utamanjene)". ${ }^{15}$ Josimović writes that the "[d]amage from lack of such public places (i.e. open green areas) is not at all insignificant for psychic wellbeing and health of a great number of residents, and it is even greater for the health of the whole city.". ${ }^{16}$ In this context, the parks and boulevards of great American cities of Boston, Philadelphia, New York, and Washington, are given as examples of rational urban planning practice. Not shown in the plan, but duly listed, are the main problems, viz. shortage of drinking water and sewers, no street lighting as well as bad or inexistent paving, no rainwater drainage, and many other problems.

The main part of the book is the Chapter II, which explains the proposal, and which is organised in related subheadings, covering the issues of regularisation of urban blocks, streets and roads, markets, churches, and parks. The proposal is based on the plan of the new urban structure consisting of hundred-andnineteen perimeter blocks and a largely regular network of streets, suitable for traffic and circulation. (Figure 1) The comparison of the existing and the planned urban structures shows uncompromising radicalism of Josimović's plan, and the total change of paradigm. There is, however, a very precise rationale to this change, and the one which leaves recognisable traces of the city's historical identity. In other words, the plan could rather be understood and read as a palimpsest, then as an inscription on a tabula rasa. Indeed, Josimović's erasure was radical, but only to the point where the traces 


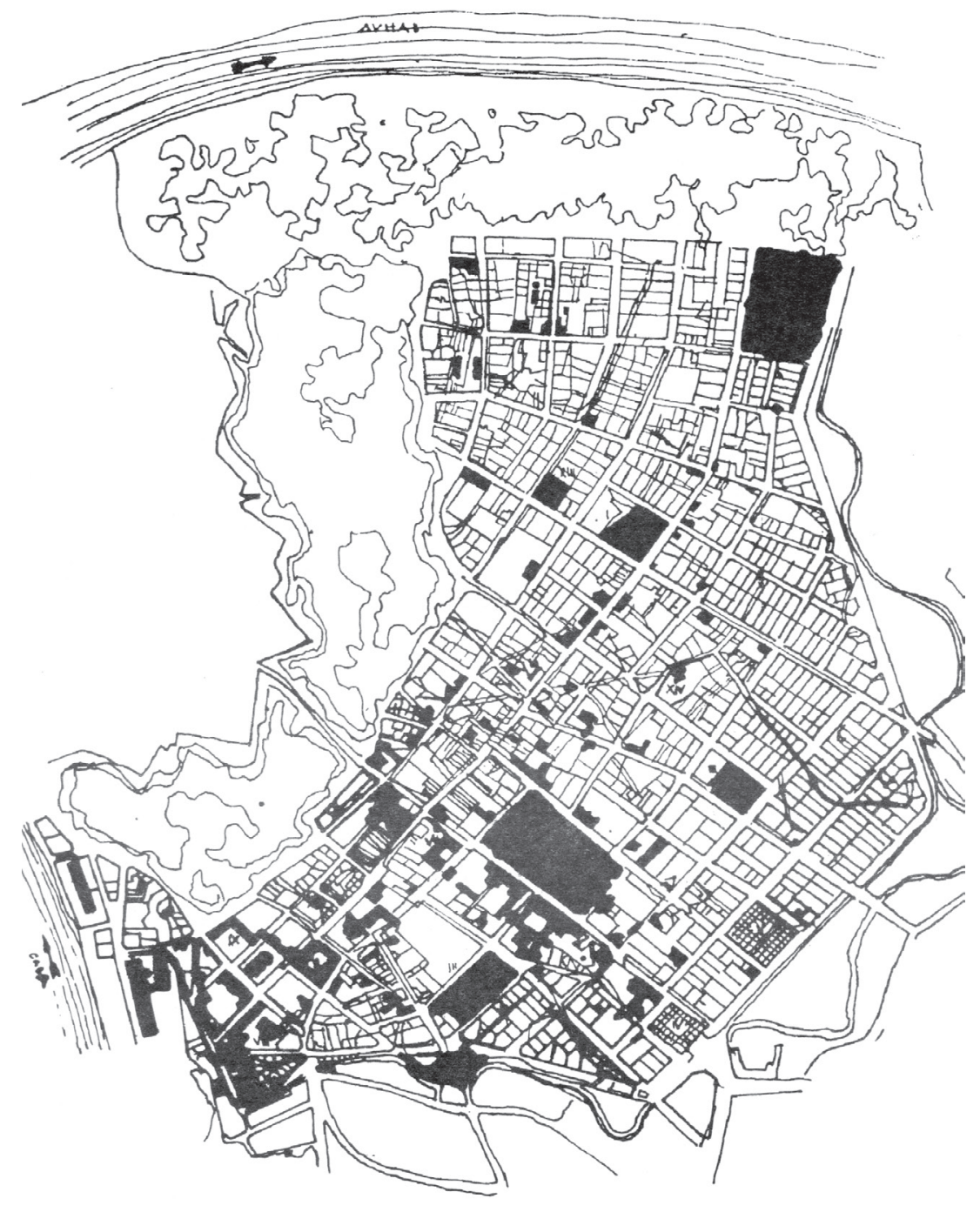

Figure 1 .

Emilijan Josimović, Plan of Regularisation of Belgrade, 1867. 
of historical identity could still be read, even if only as layers of a mental memory of the past realities. (Figure 2)

In technical terms, where possible and practical, the new plan follows the pattern of the principal existing streets, taking care that not many private properties are affected in a major way by the regularisation, but also gives provision for their widening and incorporation into the planned network. All dead end streets are closed, and the widths of the new streets range from $8 \mathrm{~m}$ and $10 \mathrm{~m}$ for side and secondary streets, to $12 \mathrm{~m}$ and $16-17 \mathrm{~m}$ for main and principal streets. The maximum slope of $1 / 10$ is regularised, as all the streets are designed for traffic. Most importantly, Josimović makes an immediate provision for the three new roads (in addition to the four existing ones), and another three for hypothetical future development, connecting the inner with the outer city, foreseeing that the two parts "... must not be two different towns, but a single, intimate one". ${ }^{17}$

Specific detailed provisions are made for new markets and churches. The only existing market, the Large Market as it was called, located in the heart of the old town in front of the Capitan Miša's Foundation, was deemed unsuitable as a place of commerce, for the reasons of its central position being appropriate for, as Josimović writes, "something else, more aesthetic". ${ }^{18}$ The plan, thus, proposes the slight enlargement of the market square, its regularisation, and planting of greenery. To compensate for this change of use, Josimović plans for three new markets positioned in such a way to serve optimally all parts of the old town. The former large market, now the main town square is envisaged as a green public space, with the character of plantation reflecting its function as an important traffic and pedestrian thoroughfare. The proposed layout of tree lined streets and pavements along the perimeter block fronts, leaves the area in the middle free for public leisure. The central feature is a large circular lawn surrounded by paths, smaller circles and semicircles with benches, and orchestra stands, and planted with low greenery and hedges to allow for the views across the square. Josimović also suggests the square would be suitable for placement of a monument in its centre, or even a "beautiful church in pure Byzantine style", consecrated to St. Sava. ${ }^{19}$ In addition to this suggestion, and the existing Cathedral Church, three new Christian Orthodox churches are proposed. The plan is, however, rather vague regarding the mosques. In a few carefully chosen words Josimović remarks on the necessity to tightly regularise the parcels of all but two mosques, and notes the monuments which stand in collision with the plan. He specifically points out to the ruins of Prince Eugene's Palace, the Mosque of Bayram Bey, and the Türbe 
Mosque, and concludes with a note which passes the responsibility of decision to the authorities.

In addition to regularisation of streets within the inner part of the city and the ones connecting it with the outer part, the plan proposes a kind of a ring, or rather a green belt encircling the town along the Moat. Josimović envisages all the land within the former Moat to be turned into six interconnected public parks of varying sizes, ranging from $1,713 \mathrm{~m}$.sq. for the smallest one to $18,383 \mathrm{~m}$.sq. for the largest. "As regards these six parks, I cannot restrain myself from but giving another one of my very modest and, I hope, suitable opinions.", writes Josimović, and continues with an idea to name each of the parks after some of the "best known benefactors of the Serbian people", and, in time, erect monuments in each of the parks, to personalities after which they were named. ${ }^{20}$ The particular choice of historical personalities reflects the ethos of Josimović's plan - paying homage to Karađorđe and Prince Miloš points out to its foundation on the political project of liberation from the Turkish rule, the homage to Captain Miša Anastasijević indicates its rationale in the rise of free economy of the liberated Serbia, and, finally, the homage to the three key contemporary intellectual figures such as Dositej Obradović, Lukijan Mušicki, and Vuk Karadžić, indicates its spirit of enlightenment and radical reform towards Europeanization.

In formal terms of the planning itself, and if compared to Vienna, it can be argued that there is a clear influence of forming a ring zone of green and open urban character in place of the demolished ramparts. Josimović, however, departs from this well known model and introduces what he calls the town wreaths / ghirlanda della città / gradski venci. The planning of the town wreaths connecting the parks in the areas of the former Moat represents the most characteristic feature of the plan, and the one which demonstrates Josimović's own, to put it in today's language, environmentalist philosophy. The total length of town wreaths is ca. $2.5 \mathrm{~km}$, their width varying between $121-656 \mathrm{~m}$. They are regularised as a loose sheaf of traffic roads, riding paths and wide pedestrian promenades set into a lush plantation landscape of interconnected free form parks. In this way, the proposal provides for the most pleasant connection and scenic route between the banks of the Sava and the Danube rivers, which encircle the inner town. More importantly, the town wreaths form, as I would propose, an ingenious seam between the inner and the outer town, making the connection between the two most attractive public spaces of the whole city. The public parks along the town wreaths cover ca. $45,000 \mathrm{~m}$.sq. area, and they connect with the Botanical Garden by the Danube 
Figure 2 .

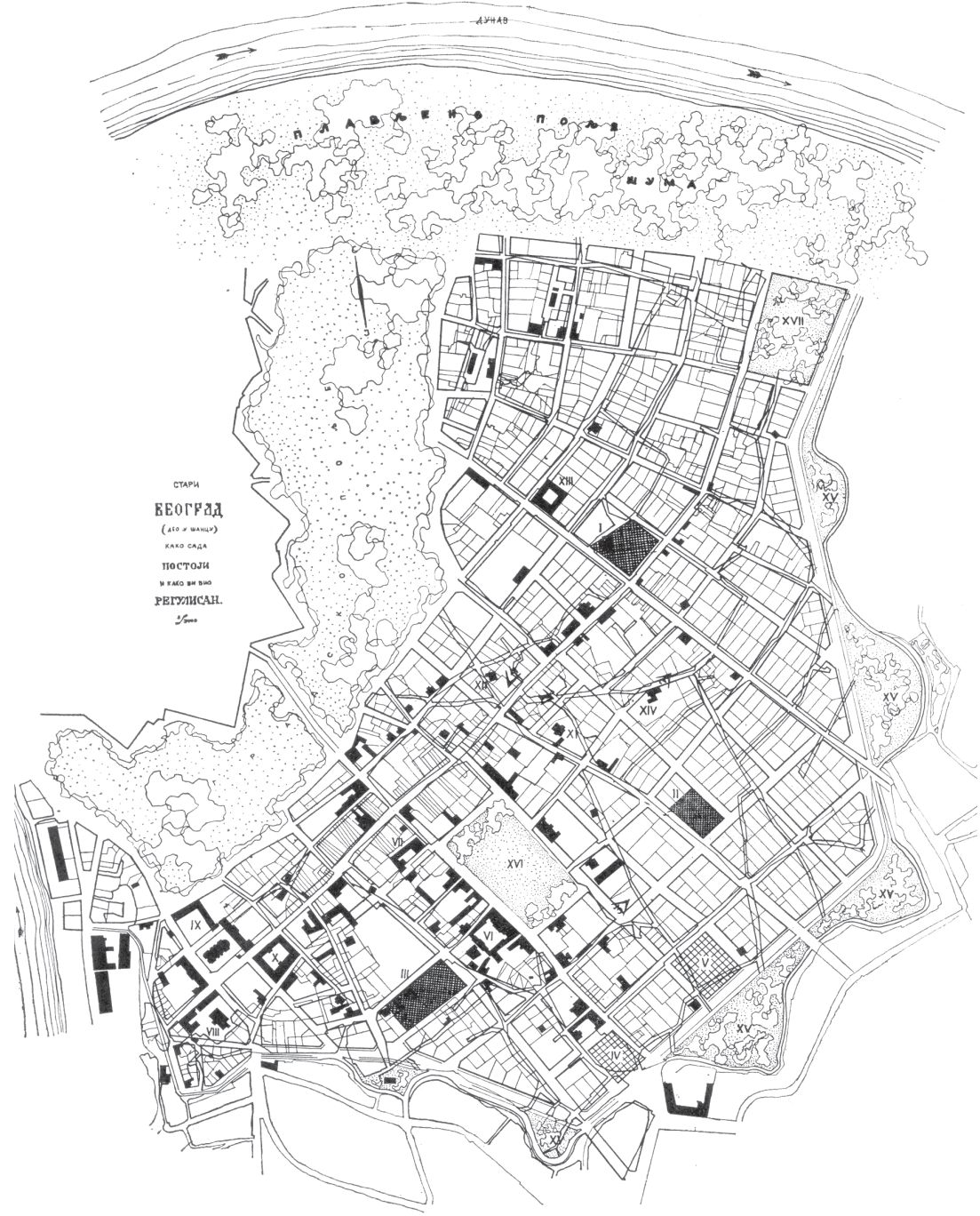


covering additional $17,500 \mathrm{~m} . \mathrm{sq}$. By leaving the town wreaths and parks as free public spaces designated solely for circulation, recreation and leisure of citizens, the plan departs from the Viennese model and its powerful architecture of state and culture institutions. While understanding the need for modern planning in line with the European trends, Josimović clearly sees Belgrade reconstruction not as copying the imperial European capitals, but as creating an idiosyncratic urban structure incorporating parks and green town wreaths, which will be tailored so as to provide beauty, satisfaction and healthy environment to its citizens. Particularly illustrative proposal is the proposal for the future use of the Kalemegdan field and the Belgrade Fortress. Josimović strongly advocates the demolition of military ramparts, and the inclusion of the whole area of the fortress into the city as a public space and park. He takes this argumentation further in the final Chapter V, and makes a strong concluding point about the relation of the Fortress, as he calls it the City, and the rest of Belgrade, as follows:

Under the cannons, whosever they might be, not one town has ever flourished, nor it ever will. The City (i.e., Fortress) is at all times, be it peace or war, a certain enemy of its country. The danger of the City and the constant dread it emanates, is one of the most damaging hindrances for trade and work, and to welfare in general, and not only to its immediate environment, but to the whole state. Therefore, Belgrade will never prosper as it could, and it will not raise itself to the higher level of welfare, until the City is demolished and its site is united with the rest of the town space. ${ }^{21}$

It is important to stress that Josimović's plan never gives in to ambitious or unsubstantiated proposals, or to representational and purely symbolic strategies. It is, to put it simply, the mathematician's plan, following verbatim its author's moto "My belief - number and measure", ${ }^{22}$ a plan, in other words, based on rational and humanistic principles.

Chapter III gives numerical data and comparative tables between "the old and the new" - the existing and the planned urban structure - with regard to land policy, and relation of private and public ownership and responsibility for the regularisation plan implementation. The introductory table shows the existing town land area within the Moat of total ca. $870,000 \mathrm{~m}$.sq., comprising the larger portion owned by the state, including the areas previously owned by the Turks, ca. $470,000 \mathrm{~m} . s q$. , public area of the Large Market of ca. $28,000 \mathrm{~m}$. sq. and some $374,000 \mathrm{~m}$.sq. of land privately owned by the Serbs and the Jews together. Josimović calculates that the full implementation of the regularisation plan 
would cover some $755,000 \mathrm{~m}$.sq. net area, and the total expenditure for regularisation would be some $13.3 \%$ of area, ca. $87,000 \mathrm{~m}$.sq. of state owned, and ca. $30,000 \mathrm{~m}$. sq. of privately owned land. He concludes this Chapter with the argumentation and proposal for renaming the streets, and numeration of parcels and houses. Chapter IV lays down proposals for implementation, including procedures, responsible institutions, dynamics of works, principles for calculations of value of land and cost of regularisation, and safeguarding the interests of all parties involved, the private owners of land, the city, and the public interest at large.

Concluding remarks, provided in the Chapter V, summarise the principal points regarding the relation of the free Serbian city and the Fortress which was, at the time, still held by the Turkish garrison. The unification of the two parts is deemed essential for the future development of Belgrade as one of the most important commercial centres in the continental part of Eastern Europe. The potentials of such a change are explained through the following points: relatively simple and inexpensive realisation of multiple connections between the fortress and the city, potential for the construction of the perimeter river key along the Sava and the Danube, the new river port on the Danube, the tunnel under the Kalemegdan ridge connecting the Sava and the Danube ports, with the future railway link as well, and the possibility of introducing modern systems for water supply and streets lighting. As for the whole Kalemegdan area, Josimović insists on it being transformed into a public park. ${ }^{23}$

Josimović's work initiated passing of the first urban act, the "Law on Regularisation of the Town of Belgrade", in $1867 .{ }^{24}$ In the following decades by the end of nineteenth century, the reconstruction of the inner city central parts and the areas towards the Sava was carried out parallel with the rapid development and regularisation of the parts of the outer city. As Zarić's plan from 1878 shows, ${ }^{25}$ the reconstruction of the old urban structure in the first ten years after the plan was undertaken was at an impressive scale. The concept of the town wreaths, however, had been largely compromised, and by 1893 , as Bešlić's plan ${ }^{26}$ aptly demonstrates, it was completely abandoned. Notwithstanding attempt to follow Josimović's planning principles, this was limited only to the plan of the block structure on the Eastern perimeter of the inner city. Josimović's call for understanding the value of the concept of the town wreaths, and I paraphrase - let all those who have the least of imaginative power and real taste, be the judges of how much would be gained for the beauty of the town, for the pleasure of its inhabitants and their health ${ }^{27}-$ fell, alas, on deaf ears. The same happened to other visionary proposals he had, 
such as the one for constructing the tunnel under the Kalemegdan ridge, which would optimise the technical performance of the river ports and traffic in general, and which would be relevant even for contemporary planning strategies.

\section{THE TWENTIETH CENTURY PLANNING: NEW PARADIGMS}

If put into the well known timeline of the long nineteenth century, as proposed by Eric Hobsbawm, Josimović's plan coincides with "the age of capital", following after the liberation struggles, which could arguably be seen as part of the great European "age of revolution". ${ }^{28}$ In that sense, this plan was a quintessentially nineteenth century undertaking, an inventive, rational, and humanist project based on the ideas of advance of the sciences and the belief in the decisive course towards material and moral progress. Furthermore, being conceived and carried out by a mathematician, it is truly a modern plan in which symbolic and aesthetic aspects are minimised and secondary to those of social, functional, hygienic and engineering nature. The "age of empire" and the beginning of the twentieth century brought new paradigms, in the political and social spheres as well as in city planning. In this new age, Belgrade turned its back to Josimović's ideas of healthy and comfortable environment, and looked for beauty in the imperial power, grandeur and monumentality of the great European cities.

The first plan to visibly manifest the ambitions of this period was the Master Plan of Belgrade, i.e., Plan d'embellissement de la ville de Belgrade, by Alban Chambon, from 1912. ${ }^{29}$ Commissioned at the time of the Balkan Wars, this plan reflects the state's majestic visions for its capital city. This is particularly displayed in the part of the Master Plan documentation comprising perspective views of squares and city prospects of grand urban design and ostentatious architecture of major state and public buildings. In this plan and its illustrative perspective sketches, which were designed in the typical European academic tradition of the nineteenth century, all visible traces of Belgrade's complex urban history and its multiple, even hybrid, identities are erased. Similarly grandiose plans followed after the First World War, when Belgrade became the capital of a new and significantly enlarged state, the Kingdom of the Serbs, the Croats and the Slovenes (SHS). ${ }^{30}$ The most illustrative example of this period is the plan by Viennese architects Erwin Ilz, Rudolf Perco and Erwin Böck, titled "Singidunum Novissima", and submitted to the International Competition for the Master Plan of Belgrade in 1922, awarded one of the highest ex-aequo prizes. The plan proposes a radical reconstruction of the city, which totally 
negates Belgrade's topography and its urban character. The period editorial comment published in Der Städtebau, accurately diagnoses the hypertrophy of the competition programme reflecting the new Kingdom's overrated assessment of its own might. As the editorial comment reads, this competition revealed an ambition which was based on an equally "egocentricmegalomaniac attitude", which had been present in similar plans for many an other capital city of the new states formed after the demise of the AustroHungarian empire, and which resulted in "bombastic planning". ${ }^{31}$

Despite the impracticable and totally abstract nature of these two plans, which made them impossible to realise, or even to consider them as viable for implementation, both had a powerful symbolic resonance. Drawn up in the crucial historical moments of the empowered state of enlarged territory, such as that of the Balkan Wars, or when Belgrade became the capital of the Kingdom of the Serbs, the Croats and the Slovenes in the aftermath of the First World War, these plans reflected the state's strive to ascertain the changed condition of sovereignty. In these moments of historical change, planning represented not only the physical intervention, but the intervention in historical time, whereby the beginning of a new history was re-established as a tabula rasa. ${ }^{32}$ In that, the urban planning was understood as an instrument which might render complex social and historical space homogenous. Yet, as Henri Lefebvre points out, "[t] he instrumental homogeneity of space, however, is illusory", and the use value of urban space understood as abstract and homogenous space is exclusively political. ${ }^{33}$

In conclusion, I would contend that the changed historical context of the twentieth century rendered Josimović's plan of regularisation to selective and highly ideologized reading, taking only the notion of erasure and the condition of tabula rasa as constitutive paradigms and as an ideological foundations of the Belgrade urbanism. As the illustrative of this point is the reading of Josimović's book by Branko Maksimović, the authority on planning history who greatly admired the 1867 Plan and wrote extensively about it and its broader consequences. In his book Ideological Evolution of Serbian Urbanism, published in 1978, by the Serbian Academy of Sciences and Arts, Maksimović defines Josimović's work as the ideological foundation of Serbian urbanism, and underlines the following point from Josimović's rhetoric, as quoted “.... that we (Serbians) are a nation which broke off totally with the old obscure Asian customs and prejudices, and that all which is progressive, beautiful and good now adheres to us." ${ }^{34}$ I would argue that this reading, as well as plans of the similar ethos, reduced Josimović's strategy to the flatness of a mirror, or more precisely, to planning as mere reflection of ideology. 
Quite the opposite view which I would argue in favour of is that the urban space that Josimović planned was a new public and social space of the liberated Serbia in the nineteenth century. This bequeathed to the future development a heterogeneous Belgrade in which the histories and differences were played out in a singular intimate city. Even when radically erasing the Ottoman urban structure, Josimović left significant traces of past histories while projecting the new one. Finally, "[t]o live is to leave traces", wrote Walter Benjamin ${ }^{35}$, and for Belgrade it is the traces of its Oriental past, such as the Bayrakli Mosque, the only remaining Ottoman mosque, which testify to the complexity of its life. ${ }^{36}$

\section{NOTES}

N.B.
All translations from the Serbian sources are by the author of this text, and original text is quoted in the endnotes.

Belgrade City Museum, engravings collection, GI1/1447

Belgrade City Museum, engravings collection, GI1/141

Brusch's plan of Belgrade, 1789 (Kriegsarchiv Wien, G Ib 49), published in: Željko Škalamera, Prilog proučavanju kartografskih izvora za istoriju Beograda XIX veka, «Godišnjak grada Beograda», no. XIV, 1967, 177; and in Divna Đurić Zamolo, Beograd kao orijentalna varoš pod Turcima 1521-1867, Beograd, Muzej grada Beograda, 1977, illustration no. 89

See: Turkish plan of Belgrade, 1864, published in: G. Elezović, and P. Popović, Dva turska plana Beograda, «Beogradske opštinske novine», no. 1-3, 1937, 66; and republished in Divna Đurić Zamolo, Beograd kao orijentalna varoš, ill. no. 90.

On architects, and architecture of the nineteenth century Belgrade, see: Nada Andrić, ... et al., Beograd u XIX veku, Exhibition catalogue - book 7, Zagreb, Muzej grada Beograda, 1968; Bogdan Nestorović, Arhitektura Srbije u XIX veku, Beograd, Art Press, 2006 (original manuscript and photographs at the Archive of the Serbian Academy of Sciences and Arts, no. 14410); Divna Đurić Zamolo, Graditelji Beograda 1815-1914, Beograd, Muzej grada Beograda, 1981; and 
Divna Đurić Zamolo, Beograd 1898-1914 iz arhive Građevinskog odbora, Beograd, Muzej grada Beograda, 1980; Mirjana Roter Blagojević, Arhitektura građevina javnih namena izgrađenih u Beogradu od 1868 do 1900. godine, «Arhitektura i urbanizam», no. 12-13 (2003), no. 14-15 (2004), 109-121, 73-90.

See: Miroslav Jovanović, ... et al, eds., Živeti u Beogradu, 1, 1837-1841. Dokumenta Uprave grada Beograda, Beograd, Istorijski arhiv grada Beograda, 2003, document no. 249. and no. 262, 358-9, 370.

Plan by captain König, 1854 (Kriegsarchiv Wien, G Ib 53), published in: Željko Škalamera, Prilog proučavanju ..., 181, quotation p. 184.

A total number of 56 mosques ( 52 by the end of 17 th, and 4 in 18th century) had been recorded in Belgrade during the period of Ottoman rule. Đurić Zamolo, Beograd kao orijentalna varoš ..., 21. In 1834, Belgrade had total of some 12,700 inhabitants, as follows: 5,503 Serbs and 1,530 Jews in 769 houses, and 5,704 Turks - 4,600 civilians and 1,104 soldiers - in 830 houses. The census of 1847 lists total of 13,724 inhabitants. Beginning of 1860s, Christian orthodox households numbered some 2,000, out of total ca. 3,100 houses. Cf.: Miroslav Jovanović, ... et al, eds., Živeti u Beogradu, 1-4, 1837-1841, 1842-1850, 1851-1867, 1868-1878. Dokumenta Uprave grada Beograda, Beograd, Istorijski arhiv grada Beograda, 2003-06.

Emilijan Josimović (1823-1897), born in the village of Old Moldova, in Banat, Caraş-Severin County, Romania. After elementary and secondary school mathematical and military education in Caransebes and Lugoj (Romania), he finished masonry trade in Vienna, studied philosophy and natural sciences at the Vienna University, and graduated in engineering and architecture at the Vienna Polytechnic. In 1845 he moved to Belgrade, and was appointed, as follows: 184551 contractual professor of the Lyceum (1849 Rector of the Lyceum. In absence of the original document of appointment, see period source quoted by B. Maksimović and D. Đurić Zamolo: Milan Đ. Milićević, Dodatak pomeniku od 1888: znameniti ljudi u srpskoga naroda koji su preminuli do kraja 1900. g. Beograd, Čupićeva zadužbina, 1901, 68-69); 1850-54 contractual professor, and 1854-69 Full Professor of the Artillery School; 1864-69 contractual professor, and 1869-78 Full-time Professor at College School/Velika škola (former Lyceum), 1876-77 Rector of College School/Velika škola; and retired in 1878. His teaching subjects included mathematics, descriptive geometry, geodesy, military science, mechanics and physics, and civic architecture, and he published 11 books in these fields of study. Full member of the Society of Serbian Letters (Društvo srpske slovesnosti) in 1848, and, from 1864, of the Serbian Learned Society (Srpsko učeno društvo), and honorary member of the Serbian Royal Academy, from 1892. One of the founders and the first President of the Technical Association (1868), and, also, one of the founders of the First Belgrade Singing Society (1853). After retirement in 1878, he moved out from Belgrade, to Lazarevac, and Soko Banja, where he died on 25th May 1897. For biographical details, see: Pismo Emilijana Josimovića predsedniku Glavnog prosvetnog saveta Stevanu Popoviću [1887], rpt. in: «O Emilijanu Josimoviću, izabrani tekstovi», Beograd, Društvo urbanista, 1997, 9-16; Divna Đurić Zamolo, Prilog biografiji Emilijana Josimovića [1976], in: Ibid., 17-56; and Branko Maksimović, Emilijan Josimović, prvi srpski urbanist, Beograd, IAUS, 1967. See: Branko Maksimović, Arhitektonska teorija Emilijana Josimovića, «Godišnjak Muzeja grada Beograda», no. III, 1956, 295-301.

The penultimate mosque which survived in Belgrade until 1897 was the Mosque of Bayram Bey which remained on the same site where the National Theatre was constructed. In 1870s, it was converted into a gas factory for the theatre, with the tall chimney built next to it, as shown in Felix Kaniz's drawing from ca. 1875. At roughly the same time it was renamed as the Black Mosque, for the reasons of its walls turning black from the gas factory smoke. Đurić Zamolo, Beograd kao orijentalna varoš ..., 25-28, ill. nos. 4, 5 (F. Kaniz's drawing). Šancu, sa jednim litografisanim planom u razmeri 1/3000. Beograd, Državna knjigopečatnja, 1867, Reprint, Beograd, Muzej primenjene umetnosti i JUGINUS, 1987 (original in the National Library of Serbia, Belgrade). 
"Uz gotovo trogodišnji veliki trud i dangubu oko premerenja varoši i predlogu za njenu regulaciju, - uz tolike pretrpljene nepovoljnosti sa s v i h strana u tom poslu, - najposle i uz znatnu novčanu štetu, koju sam njega radi imao, - mišljah: ovo će mi biti najmanja žrtva za tako korisnu stvar, ako još i ovo objasnenje projekta izdam o svom trošku, bez ikakve koristi za sebe - i tako knjiga iziđe.", Ibid., not paginated.

Ibid., 3 .

"Šteta zbog oskudice u takvim javnim mestima nije mala za duševno raspoloženje i zdravlje velikoga dela žiteljstva, ali je veća za zdravlje cele varoši.”, Ibid. p. 3

"Da to pak za življi, lakši i koristniji saobraštaj između jednoga dela varoši i drugoga nije dovoljno, i da spoljnja i nutrašnja varoš, ..., i pak nesmedu biti dve osobene varoši, nego samo jedna, prisna", Josimović, Objasnenje predloga ..., 9.

Ibid., 16.

Ibid., 19.

"Ne mogu se uzdržati, da dotično onih šest sadova neizjavim još jedno svoje vrlo skromno, i, nadam se, umesno mnenje. Ja bih te sadove, ..., namenuo spomenu ostalih najznatnijih dobročinaca srbskoga naroda." Ibid., 22-3.

"Pod topovima, ma čiji bili, još nijedna varoš nije procvetala, niti će kadgod koja procvetati. Gradovi su u svako doba, mirno ili ratno, izvestni neprijatelji one zemlje gde se nalaze. Opasnost, kojom neprestano groze, jedna je od najštetnijih zapinjača u trgovini i radinosti, dakle u blagostanju uobšte, i to ne samo obližnjih mesta, nego baš cele države. S toga ni Beograd nikako neće onako napredovati, kao što bi po svima okolnostima mogao, i na onu se visinu blagostanja podići, koju svi želimo, dokle god se grad ne poruši i njegovo se mesto sa ostalom varoši ne sastavi.", Ibid., p.43

"Moja vera - broj i mera", moto engraved on Josimović's stamp, as noted in: Maksimović, Emilijan Josimović ..., 20. Ibid., 43-5.

"Zakon o regulisanju varoši Beograda", Drž. savet br. 349/867, akt Ministarsva finansija od 6. 8. 1867., State Archive of Serbia, as noted by in: Branko Maksimović, Emilijan Josimović ..., n. 45. Plan by Stevan Zarić (1878) is available for viewing at the official web presentation of the Town Planning Institute of Belgrade, http://www.urbel.com/default.aspx?ID=uzb_BG_ planovi\&LN=SRC (as visited on 5th May 2008 by the author of this paper).

Plan by Jovan Bešlić (1893) is available for viewing at the official web presentation of the Town Planning Institute of Belgrade, www address as above.

"Koliko bi se tim naređenjem dobilo u lepoti varoši, u udovoljstvu žitelja i u zdravlju, ..., to ostavljam sudu svakoga, koji ima i najmanje uobrazne snage i pravoga ukusa.", Josimović, Objasnenje predloga ..., p. 13.

Eric Hobsbawm, The Age of Revolution, 1789-1848 (1962), The Age of Capital, 1848-1875 (1975), The Age of Empire, 1875-1914 (1987).

In her recent book, the historian D. Stojanović mentions this plan, dating it to 1908, and claims that the plan is lost, i.e. "not preserved". Cf. Dubravka Stojanović, Kaldrma i asfalt, urbanizacija i evropeizacija Beograda 1890-1914, Beograd, Udruženje za društvenu istoriju, 2008, 34-35. This is, however, in contradiction to previous research on urban history of Belgrade. Most notably, the reproduction of the plan was published and correctly dated to 1912, as reconstructed from the original documentation by the French-Belgian architect Alban Chambon (1847-1928), whose collection is kept at the Archives d'Architecture Moderne, Bruxelles. See: Milka Milatović, Alban Šambon: Generalni urbanistički plan Beograda, «Godišnjak grada Beograda», no. XXVII, 1980, 221-238; Miloš R. Perović, ed. Iskustva prošlosti, Beograd, Zavod za planiranje grada Beograda, 1985, 8-9, 11-13. This plan is also available for viewing at the official web presentation of the Town Planning Institute of Belgrade, http://www.urbel.com/default.aspx?ID=uzb_BG_ planovi\&LN=SRC (as visited on 5th May 2008 by the author of this paper). Arhitektonski fakultet i Zavod za zaštitu spomenika kulture grada, 2007. 
"Aus dem internationalen Wettbewerb um einen Bebauungsplan für Belgrad veröffentlichen wir den Entwurf der österreichischen Arhitekten Rudolf Perco, Erwin Böck und Erwin Ilz, Wien (Taf. 48). Leider war es unmöglich, das Ergebnis des Wettbewerbes in umfassenderer Weise zu veröffentlichen. Die österreichischen Nachfolgestaaten wetteifern darin, städtebauliche Projekte aufzustellen, die ihrer eigenartigen, sehr hypertrophischen Selbsteinschätzung in der Bombastik der Planung zu entsprechen scheinen. Nach Belgrad schrieb Prag einen Wettbewerb aus, der auf Voraussetzungen basierte, die auch bei bester Wirtschaftsentwicklung des Tschechenstaates und bei jahrzehntelangem europäischen Friedenszustand niemals erreicht werden wird. Das eigenartige Gefühl des Sich-Rächen-Müssens an Wien sollte für eine gesunde Planung keine Rolle spielen. Jetzt ist ja auch ein städtebaulicher Wettbewerb für Spalato ausgeschrieben, der auf ähnlich irrigen und egosentrisch-megalomanen Einstellungen beruht. - Unabhängig davon bleibt zu hoffen, daß wenigstens Entwürfe von Rang bei dieser Gelegenheit geschaffen werden.” Schriftleitung, Wettbewerb: Belgrad, «Der Städtebau» (Berlin), 19. Jahrgang, 1922/23, 121. Blagojević, Novi Beograd: osporeni modernizam, 247. Henri Lefebvre, The Production of Space [1974], translated by Donald Nicholson-Smith, Oxford, Blackwell Publishing, 1991, 285.

Original text by E. Josimović, quoted and underlined in: Branko Maksimović, Idejni razvoj srpskog urbanizma: period rekonstrukcije gradova do 1914, Beograd, SANU, 1978, 44. Walter Benjamin, "Paris, the Capital of the Nineteenth Century (Exposé of 1935)", in Reflections, translated by Edmund Jephcott, New York, Schocken Books, 1986, 155. monument of culture.

Figure 1. Emilijan Josimović, Plan of Regularisation of Belgrade, 1867, published in: Emilijan Josimović Objasnenje predloga za regulisanje onog dela varoši Beograda što leži u Šancu, Beograd, Društvo urbanista, 1997, 25.

Figure 2. Branko Maksimović, Comparative plan of survey and proposal for reconstruction of Belgrade by Emilijan Josimović (1867), published in: Branko Maksimović, Idejni razvoj srpskog urbanizma: period rekonstrukcije gradova do 1914, Beograd, SANU, 1978, 45, illustrationa no. 31. 